\title{
Peridynamics 破壊力学を用いた板ガラスの破壊解析に関する基礎的検討
}

Basic Study on Fracture Analysis of Flat Glass using Peridynamics Fracture Mechanics

\author{
柴田 良一・岐阜工業高等専門学校 \\ 建築学科
}

Ryoichi Shibata, Gifu National College of Technology, Dept. Architecture

Key Words: Peridynamic Fracture Mechanics, Fracture Analysis, Flat Glass

\section{論文要旨}

建築物の強風による被害の中で飛来物の衝突によるものは、自然環境や飛来物体の条件も多様であり評価が困難な問題とされ ている．例えば、建築空ガラスに対して台風などによる飛来物の衝突は、貫通した場合には気圧差により構造物全体を崩壊に導 く恐れが指摘されている，そのため限定的な条件における実験的手法により、破壊現象の評価が進められているが対象条件も限 られている. そこで数值解析的手法により破壊解析を実現できれば、様々な条件設定での破壊現象が評価できることが期待され ている.そこで本研究では、Peridynamics 破壊力学を用いた数值解析を行い、実験的手法で得られた破損状況との定性的な比較 を目的としている.

\section{1. 研究目的}

建築物の中で空ガラスは台風の影響を受けやすい脆性材 料のひとつである. 空ガラスが欠損すると, 強風が室内に吹 き込み，それが原因となる二次被害に慗がりかねない，強風 の吹き込みによる建築物の被害の原因には以下の 2 つが挙 げられる

(1) 飛来物の衝突による空ガラス欠損

（2）許容耐力を超える風圧が作用した場合の空ガラス崩壊

建築物の建設において, 各部材は許容耐力基準をもとに設 計されている，そのため，後者は未然に防ぐことが十分可能 であり, 今後は前者を防ぐことが重要となる. 各建築部材の 破壊検証は多くが実験的手法で行われているが, 大規模な建 築物になるほど, 同様の条件で実験的手法を用いるのは困難 である.またガラスの破壊は建築物だけでなく、交通機関に おいても多用されており、同様な安全確保が必要である.

本研究では, 実験で確認された板ガラスの破壊現象を数值 解析的に再現し，結果を定性的に分析することで，有用性を 検証することを目的とする.

\section{2. 研究方法}

破壊現象を，数值解析的に再現するために，亀裂や破断等 の破壊現象を定式化する必要がある．そこで今回は，対象物 全体を粒子でモデル化する手法である Peridynamics 破壊理論 を用いて解析を行 ${ }^{1)}$. この手法では, 支配方程式として積 分方程式を用いることで、一般的に数値解析で用いられる有 限要素法では困難であった破壊現象を含めた全体挙動を表 現することが可能である ${ }^{2)}$.

本研究では河井ら ${ }^{3)}$ の衝撃実験と解析結果を比較し, 分析 を行う. 比較する実験は, $20 \times 40 \mathrm{~mm}$ の角材を $12.2 \mathrm{~m} / \mathrm{s}$ (誤差士 $2 \%)$ で衝突させたものとする。 これは，ガラス開口部への飛 来物に対しての耐衝撃破壊性能評価方法である ISO16932を 検証するために, アメリカのハリケーンに対する性能標準試 験に基づく ASTM0E1886-04 の方法で ASTM0E1996-04 に定 められた加撃体条件である.

\section{3. 解析方法}

解析モデルを図 1 に示す. 解析条件は河井らの実験と同様 の条件に設定した. $900 \times 1100[\mathrm{~mm}]$ の板ガラスの端部から内
側 $30 \mathrm{~mm}$ まで四辺固定とし, $20 \times 40[\mathrm{~mm}]$ の鉄柱の速度を変 化させ，ガラスの中央部に衝突させる．本研究では衝突面を 表面, 非衝突面を裏面と呼ぶ.

各ガラスにおける解析条件を表 1 に示す．普通フロートガ ラスの解析モデルは，厚さを $05 \cdot 6 \cdot 8 \cdot 10 \cdot 120[\mathrm{~mm}]$ とした ものに, 速度 $15 \cdot 20 \cdot 250[\mathrm{~m} / \mathrm{s}]$ で鉄柱を衝突させる．合わ せガラスの解析モデルは，厚さ $5 \mathrm{~mm}$ のガラスを重ね，その 境界面のフィルムの材料特性を, ポリビニルブチラール・ポ リカーボネート(以下 PVB・PC とする)としたものに，速度 $15 \cdot 200[\mathrm{~m} / \mathrm{s}]$ で鉄柱を衝突させる.

これまでのガラス材料の研究により,ガラスの強度は表面 の細かい傷や端部の欠けなどの影響で著しく減少すること が解明されている.この現象を考慮するために設計引張強度 は、標準引張強度の $1 / 7$ 倍で計算される. 本解析ではその理 論に基づいて, 解析モデルは設計引張強度を用いて設定を行 った.

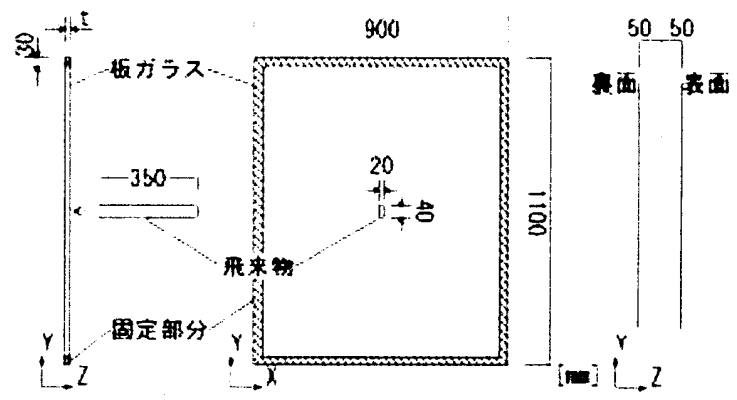

図 1 飛来物街撃実験の状態

表 1 各ガラスに対する解析条件

\begin{tabular}{|c|c|c|c|}
\hline ガラス種類 & 厚さ[ & & 衛突速度 $[\mathrm{m} / \mathrm{s}]$ \\
\hline \multirow{5}{*}{$\begin{array}{c}\text { 普通フロ一ト } \\
\text { ガラス }\end{array}$} & \multirow{2}{*}{\multicolumn{2}{|c|}{5}} & \\
\hline & & & \\
\hline & \multicolumn{2}{|c|}{$\begin{array}{l}0 \\
8\end{array}$} & $15 \cdot 20 \cdot 25$ \\
\hline & \multicolumn{2}{|c|}{10} & \\
\hline & \multicolumn{2}{|c|}{12} & \\
\hline $\begin{array}{l}\text { 合わせガラス } \\
\text { [厚さ } 10 \mathrm{~mm}]\end{array}$ & $\begin{array}{c}\text { 中間膜 } \\
\text { 素材 }\end{array}$ & $\begin{array}{l}\text { PVB } \\
\text { PC }\end{array}$ & $15 \cdot 20$ \\
\hline
\end{tabular}




\section{4. 結果分析}

4-1 普通フロートガラスについての比較

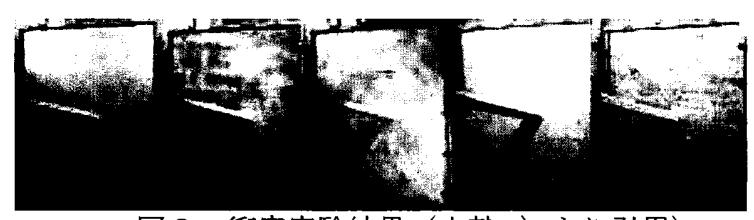

図 2 衝突実駼結果（文献 2）より引用）

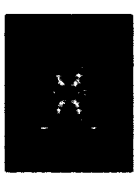

5

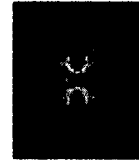

6

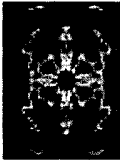

8

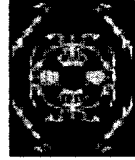

10

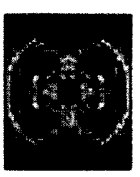

$12 \mathrm{imm}$
図 3 衝突速度 $15 \mathrm{~m} / \mathrm{s}$ での各厚さの解析結果

表 2 普通フロートガラスの実験結果

\begin{tabular}{|c|c|c|c|c|c|}
\hline [न & 5 & 6 & 8 & 10 & 12 \\
\hline 破壊筧囲 & \multicolumn{5}{|c|}{ 狭い $\leftarrow \rightarrow$ 広い } \\
\hline 破片サイズ & \multicolumn{2}{|c|}{ 荒い } & \multicolumn{3}{|c|}{$\rightarrow$ 細かい } \\
\hline 破壊形状 & 円周 & 円周 & 円周 & 円周 & 放射 \\
\hline 基通 & 有 & 有 & 有 & 有 & 有 \\
\hline
\end{tabular}

実験結果を図 2 , 表面における各厚さの解析結果を図 3 に 示す. 実験結果の破壊状態をまとめたものを表 2 に示す.ガ ラスの厚みが増すに従って破壊範囲が大きくなること，破片 が細かくなること, 飛来物が貫通することに関しては実験と 同様に確認できた，破壊形状は円周状の破壊は確認できたが， 衝突中心点から固定部まで放射状に広がる亀裂は確認でき ず，実験結果のように破片が不定形にならなかった。

\section{4-2 合わせガラスについての比較}

表 3 合わせガラスの実験結果

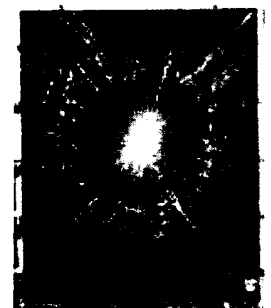

\begin{tabular}{|c|c|}
\hline 厚さ[mm] & 10.75 \\
\hline 表面破壊形式 & 円周状 \\
\hline 裏面破壊形式 & 放射状 \\
\hline 貫通 & 無 \\
\hline 中間膜素材 & PVB \\
\hline
\end{tabular}

図 4 衝突実験結果（文献 2）より引用）

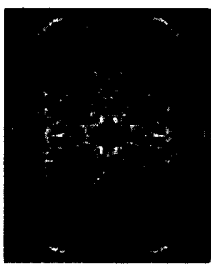

フィルムなし

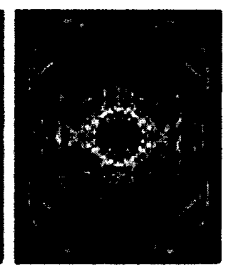

PCつィルん.

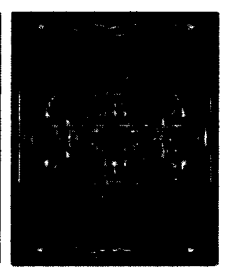

PVBフィルム
図 5 街突速度 $15 \mathrm{~m} / \mathrm{s}$ での各条件の解析結果

実験結果を図 4 , 表面にお污る各フィルム特性の解析結果 を図 5 に示す。実験結果の破壊状態をまとめたものを表 3 に 示す. 合わせガラスの破壊形式の特徴である, 表面と裏面の 破壊形式の違いに関しては, 各解析条件において表面とほぼ 同様な破壊形式となり，実験で見られた違いは確認できなか った. PVBフィルムを挟んだ合わせガラスに至っては, 飛来 物が貫通するという結果となった。

\section{5. 考察}

実験結果と解析結果が異なった大きな原因として,ガラス の状態に強く関与していると考えられる. 生産段階で生じる 表面の分子レベルでの細かな傷は方向性を持たない. 飛来物 の衝突によって生じた応力は，その傷によって偏り，規則性 を持たない亀裂を生じさせる. 解析に用いた設計引張強度も， 面上に生じた傷を考慮し平均化した值であり，それを解析モ デル全体に用いたとしても，不規則な亀裂を生じさせること はできない。

合わせガラスにおいては，別材料を挟むことで強度が増す ことは確認できたが, 両面における破壊形状の違いが確認で きなかった。これは，フィルム厚さを正確に指定できなかっ たことが主な理由として考えられる. 表面の円周状の破壊は， 衝突点へのモーメントによりフィルムに放射状の引張力が 生じることで起きるとされており，裏面の放射状の破壊は， フィルムが変形で円周状に裏面のガラスに引張力を生じさ せるためだといわれている. そのため, フィルムを正確に再 現することが必要であったといえる.

\section{6. まとめ}

本研究では, 各ガラスの破壊現象の再現を目的とし, Peridynamics 破壊理論を用いて粒子モデルの解析を行った. その結果, 厚みに対するガラス材料特有の破壊現象を再現す ることができた．しかし，本解析において設定上，ガラスの 不規則性を考慮することができず，ガラスの本質的な破壊現 象に対しては再現するに至らなかった. 今後の改善点として は, 不規則性の設定方法や, 解析に有効なモデルの粒子間設 定に関しての検討を進めていくことが必要だと考える.

謝辞

研究の実現や資料の提供については、平成 25 年度岐阜高 専建築学科卒業の市橋崇稔君の全面的な支援を受けました. ここに感謝の意を表します。

\section{参考資料}

1) S.Silling : Peridynamic States and Constitutive Modeling, J. Elasticity(2007), pp.151-184, 2007 年

2) 柴田良一, 田中正史, 加藤史郎 : Peridynamic 破壊力学 を用いた構造部材の破壊解析に関する基礎的検討一構造部 材の粒子によるモデル化と強度の検証一, 日本建築学会東海 支部研究報告集 (51), pp.349-352，2013 年

3) 河井宏允，丸山敬，西村宏昭：強風下における飛来物に よる外装材の破壊性状に関する研究，基盤研究(B) 2008-2010 年度科学研究費補助金研究成果報告書, 2011 年 